\title{
Import effect on technical efficiency of cargo ports: evidence from Italy, Slovenia, and Croatia
}

\author{
Nikolina Buljan Perusic* Jian Hua Zhang \\ School of Economics, Huazhong University of Science and Technology, Wuhan, P.R. China \\ * E-mail of the corresponding author: nikolina.buljan@yahoo.com
}

\begin{abstract}
The objective of this research is to investigate to what extent the 26 ports included in this study are technically efficient and how different factors can influence efficiency. Through the model presented, we examine the hypothesis which states that imports affect ports' competitiveness and efficiency, so they should be included in the deterministic part of the model because ports are aware of trade impact when making infrastructure changes. The research used the True-fixed Effect Stochastic Frontier model for panel data with time variance (Greene 2005) and implemented the Cobb- Douglas production function with truncated normal distribution and the maximumlikelihood dummy variable estimation method. The model outcome is presented through values of technical efficiency for ten years, and it monitors the Croatian, Italian and Slovenian ports' response at these significant periods of the European economy.
\end{abstract}

Keywords: ports, technical efficiency, Stochastic frontier model, true fixed-effects

DOI: $10.7176 / \mathrm{JESD} / 10-22-16$

Publication date: November $30^{\text {th }} 2019$

\section{Introduction}

One of the most famous findings of port efficiency is the one from Coto-Millán et al. (2000) that proved a negative relationship between efficiency and port size. Also, that is a request for researchers to use a variety of inputs to examine what is influencing port efficiency. We included imports in one of the model versions deterministic part through the hypothesis that ports are well aware of the effects of trade on port competitiveness and efficiency. Consequently, ports include trade structure in the count when they are making infrastructural changes regarding the type of storage spaces, terminal system, and other technical features. The trade effect will be compared to a model version where imports are not included in the analysis and to a model version where we put imports as an exogenous variable. We have used the Stochastic frontier model to examine the technical efficiency of Italian, Croatian, and Slovenian cargo ports over the last ten years. These countries' cargo ports became a point of interest after China announced the project-21st Century Maritime Silk Road, part of the One Belt One Road (OBOR) Initiative, in 2013. The new maritime route from China to Europe should decrease the journey by eight days if the final destinations are Adriatic seaports from where goods would keep traveling to European countries by railway. Since Italy and Croatia signed an agreement to participate in the project earlier in 2019, these ports became higher points of interest for many cargo companies. Through this research, we examined 26 ports (Figure 1) including the Italian ones that don't have an exit on the Adriatic Sea. The main inputs are technical features of ports, including total storage, availability of a port railway, the closest airport, depth of the channel, and anchorage. The output of the research is measured through the annual throughput in thousands of tons.

The purpose of the second part is to provide a review of recent research and an overview of stochastic frontier analysis usage through history and its applicability for port efficiency analysis. By the definition of Koopmans, one of the first theoretical creators of technical efficiency theory, a company is technically efficient only if it is not possible to produce more of any output without using more input or producing less of some other output. (Koopmans, 1951) Traditional regression assumes that a company should reach the maximum amount of output for a certain input, but not all companies can always get the maximum or minimum for given output. Furthermore, even if they are technically efficient, they cannot always manage to allocate their inputs in a cost-effective way. (Kumbhakar \& Lovell, 2000) To date, there has been little agreement on what model is most useful for examining port efficiency, but SFA- Stochastic Frontier Analysis and DEA- Data Envelopment Analysis are most used ones. We used Greene's (2005) version True fixed-effects (TFE) Stochastic frontier model for panel data that implements the Cobb-Douglas production function with truncated normal distribution and a maximum-likelihood dummy variable estimation method. The final section of the paper describes the results of the efficiency analysis and provides a cross-section of events that clearly shows the relationship of efficiency to the economic crisis that shook Europe and how ports behaved in the post-crisis period. The following chapter will outline the progress of ports that have been examined through the past ten years and give an overall conclusion of the research. 


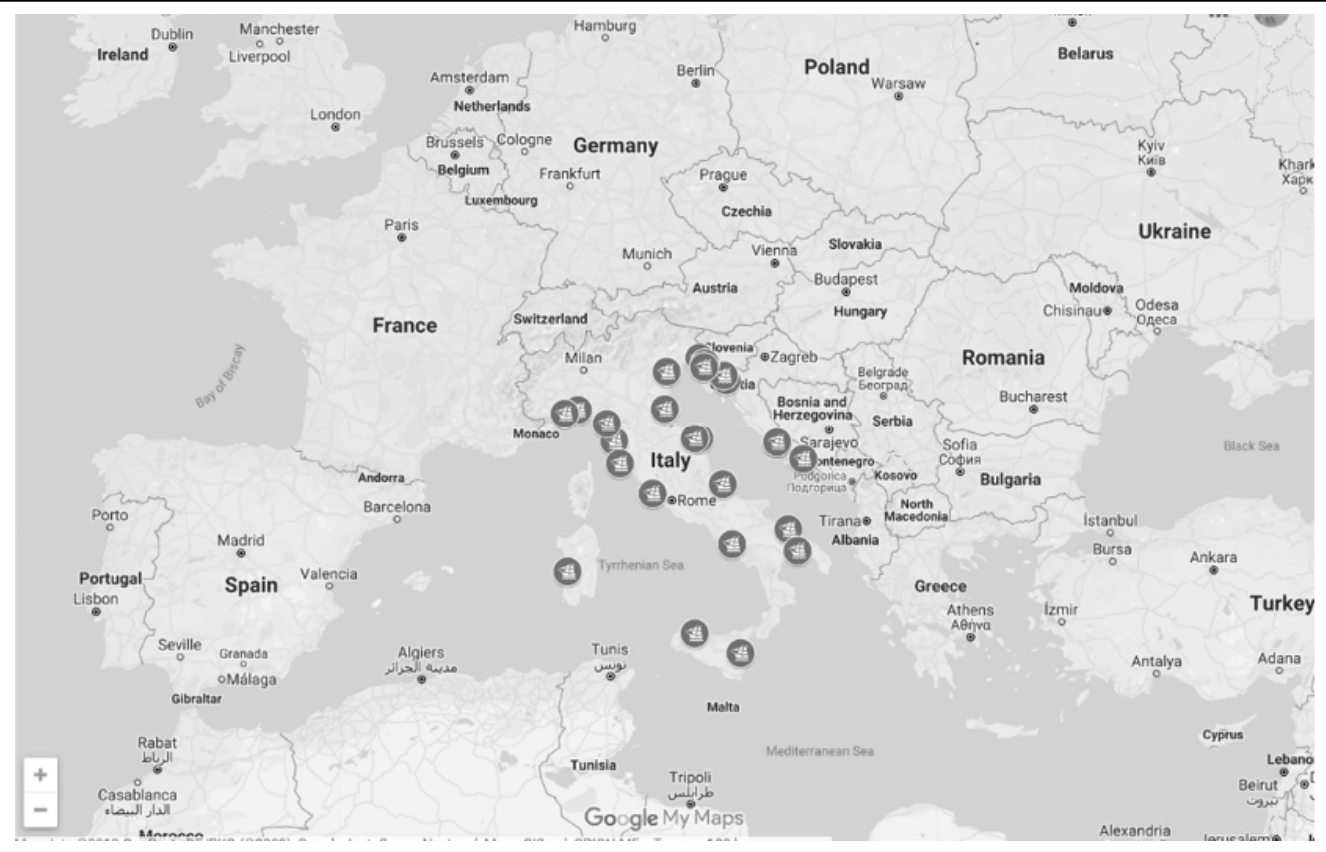

Figure 2 Examined ports location. Created by Google maps tools

\section{Literature review}

Measuring economic performance can be an ungrateful assignment or 'state-of-the-art' regarding the spectrum of potential ways and inputs that might influence that performance. (Cummins \& Weiss, 2000). Two basic approaches to measuring economic performance are measuring productivity or efficiency. There is a great correlation between the concepts of productivity and efficiency and their meaning is often mistakenly equated in the literature. Productivity should be described as a ratio between an output and a given input, and efficiency should be described as a more accurate measure because, in this theory, it involves a comparison with the most efficient frontier. (Daraio \& Simar, 2007) Frontier analysis that measures efficiency allows the researcher to use a range of inefficiency models that are changeable over time. Measurement of technical efficiency in ports needs to include clearly defined units of container ports, utilize the types of inputs to produce the same type of services as well as outputs and inputs that will indicate what services a port has and what resources it is using. (Schøyen \& Odeck, 2013) There are nonparametric frontier analysis and parametric ones. The first ones are defined under the Data Envelopment Analysis (DEA) approach that is recognizable by its mathematical programming background, and it is widely used as parametric approach - stochastic frontier analysis (SFA) which is used in statistical and econometric research (Cullinane \& Song, 2003). In port statistics, many researchers still use both analyses to stabilize the outcome of the research (Lin \& Tseng, 2005) (Odeck \& Bråthen, 2012). This regression analysis is described as follows:

$y_{i}=f\left(x_{i}\right) \exp \left\{v_{i}-u_{i}\right\}$ where $\mathrm{x}$ and $\mathrm{y}$ are inputs and outputs, $\mathrm{v}$ is the error of measurement, and $\mathrm{u}$ is the level of inefficiency. Initially, this analysis was introduced by Aigner, Lovell, and Schmidt (1997) and Meeusen and Van den Broeck (1977).

The first changes in the original model were made by Pitt and Lee (1981) in which they extended the model to longitudinal data with normal- or half-normal distribution, which is described and interpreted as follows (Belotti, Daidone, Ilardi, \& Atella, 2013):

$$
\begin{gathered}
y_{i t}=\alpha+x_{i t}^{\prime} \beta+\varepsilon_{i t} \quad i=1, \ldots, N, t=1, \ldots, T i \\
\varepsilon_{i t}=v_{i t}-u_{i t} \\
v_{i t} \sim N\left(0, \sigma_{v}^{2}\right) \\
u_{i} \sim N+\left(0, \sigma_{u}^{2}\right)
\end{gathered}
$$


A function in the form of SFA can applied as a production or cost function, and there are several function forms in the port analysis. According to the literature, the Translog function (Coto-Millan, Banos-Pino, \& RodriguezAlvarez, 2000) and Cobb- Douglas function (Notteboom, Cook, \& Broeck, 2000) (Cullinane \& Song, 2003) (Mazorodze, 2019.) (Meeusen \& Broeck, 1977) forms are the ones most used. The Cobb-Douglas function is not flexible compared to Translog, but it needs fewer observations to carry out an estimation (Liu, 2010). The Translog function can also calculate scale and substitute elasticity, while Cobb-Douglas cannot. As inputs of the SFA production forms, port researchers often use inputs of port land features such as the length of quays, the size of the terminal surface, the size of storage, and the number of berths. For output they usually use port's throughput or turnover, but there is no overall agreement on which port features affect efficiency the most. Usually, the biggest ports are also the most efficient ones because of the quality of the port infrastructure and the storage and cargohandling equipment (Kennedy, Lin, Yang, \& Ruth, 2011.)

We used Greene's version of the SFA model from 2005. He has debated that traditional panel data estimators, including fixed and random effect models, have some flaws. The first point is that panel data estimators lean towards the conclusion that cost and technical inefficiency are unchangeable over time. (Greene, 2005). In a short period, this might not cause an error, but it creates a problem in bigger panel datasets.

Furthermore, there is also a statement that through estimating fixed and random effects we cannot distinguish individual heterogeneity from inefficiency. Simplified, inefficiency measures in the mentioned models could be coming out with heterogeneity instead of inefficiency. The time invariance problem of panel data models was first noted by Heshmati and Kumbhakar (1994), but Greene was the first one who implemented several proposals to implement time factors in measuring inefficiency.

\section{Model and Data Specification}

The dataset includes 21 Italian ports, four Croatian ports, and one Slovenian port. There are some important ports like Gioia Tauro that were not part of the research because of the lack of data. Data was collected from several sources. Throughput data (Figure 2) was collected from the Eurostat ${ }^{1}$ Statistic Database, while technical data for ports were collected from Llyod's List repositories and the official websites of the ports. Trade data was collected at the national bureau of statistics of Italy, Croatia, and Slovenia. The data presented follows the period of the past ten years, and it is calculated by the 'sfpanel' command for stochastic frontier analysis in the Stata program. The mentioned period of time from 2009 to 2019 was marked by an economic crises; so, from technical efficiency results, it is very vivid how each port handled that crisis.

The model was created by Greene's panel data estimation with true fixed-effects and the truncated normal distribution (Greene, 2005). Inputs of the model are channel depth, anchorage depth, total storage, railway availability, the closest airport, and imports. The output is the throughput in thousands of tones.

Table 2 Model testing -variables description

\begin{tabular}{|c|c|c|}
\hline $\begin{array}{c}\text { Model version results } \\
\text { name }\end{array}$ & $\begin{array}{c}\text { Deterministic part } \\
\text { variables }\end{array}$ & Stochastic part variables \\
\hline $\mathrm{Te} 1$ & $\begin{array}{c}\text { Channel depth, } \\
\text { anchorage, total storage }\end{array}$ & $\begin{array}{c}\text { Railway availability, the } \\
\text { closest airport distance }\end{array}$ \\
\hline $\mathrm{Te} 2$ & $\begin{array}{c}\text { Channel depth, } \\
\text { anchorage, total storage } \\
\text { Channel depth, } \\
\text { anchorage, total storage, } \\
\text { imports }\end{array}$ & $\begin{array}{c}\text { Railway availability, } \\
\text { imports }\end{array}$ \\
\hline $\mathrm{Te} 3$ & $\begin{array}{c}\text { Railway availability, the } \\
\text { closest airport distance }\end{array}$ \\
\hline
\end{tabular}

The te 3 model version is presented below.

\footnotetext{
${ }^{1}$ https://appsso.eurostat.ec.europa.eu/nui/show.do?dataset=mar_go_am_hr\&lang=en
} 


$$
\begin{gathered}
\ln \left(y_{i t}\right)=\alpha_{i}+\beta_{1} \ln \left(x_{1 i t}\right)+\beta_{2} \ln \left(x_{2 i t}\right)+\beta_{3} \ln \left(x_{3 i t}\right)+\beta_{4} \ln \left(x_{4 i t}\right)+\varepsilon_{i t} \\
\varepsilon_{i t}=v_{i t}-u_{i t} \\
v_{i t} \sim N\left(0, \sigma_{v}^{2}\right) \\
u_{i t} \sim N^{+}\left(\mu_{i t}, \sigma_{u}^{2}\right) \\
\mu_{i t}=Z_{i t}
\end{gathered}
$$

Where:

$\alpha_{i}$ - is an intercept parameter and it is different for each port

$\beta^{\prime} x_{i t}$ - is the vector of independent variables' parameters

$y_{i}=$ throughput for container traffic in thousands of tones for the time period $(\mathrm{t})$

$x_{1 i}=$ channel depth in meters

$x_{2 i}=$ anchorage depth in meters

$x_{3 i}=$ total storage in square meters

$x_{4 i}=$ import variable

$v_{i t}=$ error of measurement (with independent, identical distribution)

$u_{i t}=$ level of inefficiency (with Truncated Normal distribution)

$Z_{i t}$ - is a vector of exogenous variables (including a constant term), exogenous variables are railway availability and closest airport

$\sigma$ - is the vector of parameters which parameterizes and shifts the mean of the pretruncated inefficiency distribution The level of inefficiency distribution (Liu, 2010) is as follows:

$$
\begin{aligned}
& \mathrm{N}\left(\mu^{i}, \sigma_{u}^{2}\right) \\
& \mathrm{f}_{\mathrm{u}}(\mathrm{u})=\frac{1}{\sqrt{2 \pi} \sigma_{\mathrm{u}} \phi\left(-\mathrm{u} / \sigma_{\mathrm{u}}\right)} \exp \left\{-\frac{(\mathrm{u}-\mu)^{2}}{2 \sigma_{\mathrm{u}}^{2}},\right\}
\end{aligned}
$$

Efficiency estimation can be calculated with the JLMS formula (Jondrow, Lovell, Materov, \& Schmidt, 1982). In this case $\mathrm{S}$ is the sign of the inefficiency term and it is positive $(+1)$ for profit production.

$$
\begin{gathered}
\hat{u}_{i t}=E\left[u_{i t} \mid \varepsilon_{i t}\right]=\frac{\sigma \lambda}{1+\lambda^{2}}\left[\frac{\phi\left(a_{i t}\right)}{1-\phi\left(a_{i t}\right)}-a_{i t}\right] \\
\sigma=\left[\sigma_{v}^{2}+\sigma_{u}^{2}\right]^{1 / 2} \\
\lambda=\sigma_{u} / \sigma_{v} \\
a_{i t}=S \varepsilon_{i t} \lambda / \sigma
\end{gathered}
$$

Regarding the fact that efficiency is time-varying, we can describe how big the inefficiency elements are in the composite error. A higher proportion means better results. To perform the test, we can use the following equation: where $\gamma$ is a factor between 0 and 1 which determines proportion of inefficiency term in composite error. In our

$$
\begin{gathered}
\sigma^{2}=\sigma_{u}^{2}+\sigma_{v}^{2} \\
\gamma=\frac{\sigma_{u}^{2}}{\sigma^{2}}
\end{gathered}
$$

case, the maximum likelihood dummy variable (MLDV) estimation method is used to fit the data. If variables affect inefficiency in negative way, it means that they have a positive outcome towards efficiency. Namely, it 
means that the same variables have a positive effect on the operation of the port, and that they are significant for its efficiency.

The central hypothesis of the research is that nowadays ports are aware of the import effects on the throughput of certain efficiencies or inefficiencies. The data for imports can be taken into consideration when making changes in port storage, equipment, and other facilities regarding the analyses of the type of goods that are coming to the ports. Besides that, we assume that import and trade, in general, can raise the competitiveness of ports and by that lower inefficiency. To examine this hypothesis, we included imports in the deterministic part of the model (te 3 model version) which can also be described as a net effect model. Net effect models are designed to include exogenous variables in the deterministic part, and ours assume that the import variable has the same impact as other technical variables of the ports that are included in model. The effect of trade on efficiency has been discussed in several papers. Some claim that trade cannot be part of the net effect model and have the same impact on output as endogenous variables, because trade is out of the spectrum of a firm. Liu (2010) mentions that in the same way that an agricultural company cannot control rain, trade cannot be controlled by the shipping industry. Others see trade as a way to improve industries in the model of learning by doing and implementing these findings in technical changes that will upgrade technical efficiency (Krugman, 1980) (Mazorodze, 2019.) To compare results, we also did the opposite and put the same variable as the exogenous part and showed the outcome of technical efficiency that compares these two approaches as well as a comparison with one where import is not a variable in the model.

We tested the previously mentioned model with different variable inputs as described in Table1. The model version in the results regarded as te 2 in the deterministic part contains variables of channel depth, anchorage, and storage. Exogenous variables in this case are railway and import. The model version in the results regarded as tel includes the variables channel depth, anchorage, and storage in the deterministic part of the model, while railway and closest airport distance are included as exogenous variables. The version tel ignores the import variable.

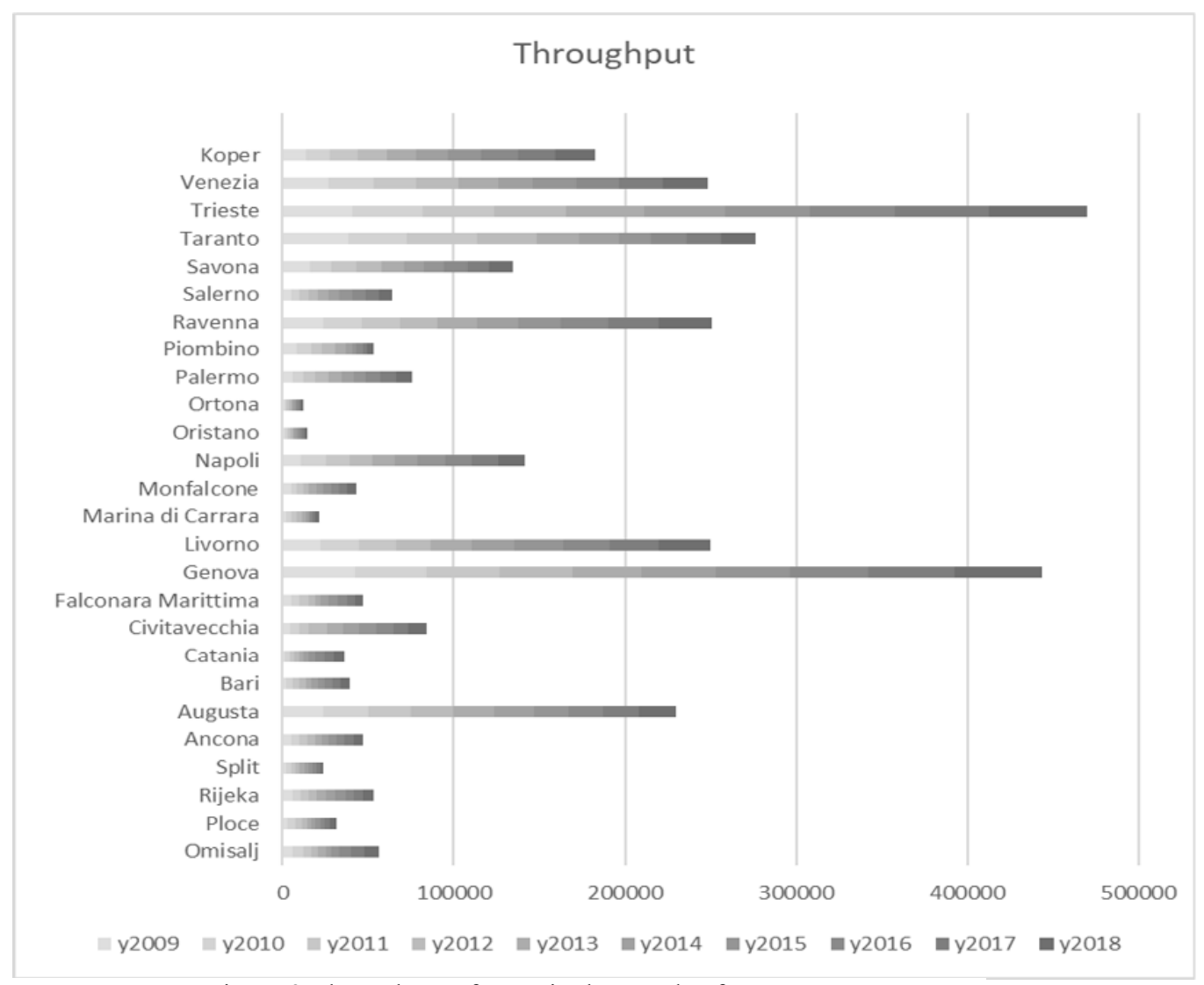

Figure 3 Throughput of ports in thousands of tons 


\section{Model Results}

It is evident for most ports, especially larger ports, that the model in which import is in the deterministic part (te3) achieves the best results for efficiency. Compared to other models, the te 3 version achieves the best results when it comes to larger ports such as the Italian ports of Trieste, Ravenna, Palermo, Genova, Livorno, Salerno, and others. Port Koper, as shown in Figure 4, has a typically healthy increase in technical efficiency through the years despite the financial crisis, rising from 0.58 in 2009 to 0.99 in 2018 . The difference in the port's technical efficiency regarding the results from different model versions can be observed in the port Koper example. This port shows an increase in effectiveness through the te 3 model version. The value in 2009 for $t e 2$ was 0.58 , while in the $t e 3$ model it was 0.63 . For the year 2014, the value in te 2 was 0.78 , while we can see an increase of technical efficiency in te3 to a value of 0.81 . But that is not the case in all large ports. For example, in port Venezia, te3 does not produce the best results for technical efficiency, while in ports like Savona, Piombino, Napoli, and Croatian port Rijeka, the model is only partially successful and only through the first few years observed.

\begin{tabular}{|c|c|c|c|c|c|c|c|}
\hline & $\mathrm{y}$ & channe $\sim \mathrm{m}$ & anchor m & closes m & raiway & totals 2 & import \\
\hline $\mathrm{y}$ & 1.0000 & & & & & & \\
\hline channeldeptm & 0.3096 & 1.0000 & & & & & \\
\hline anchoraged $\sim \mathrm{m}$ & 0.0394 & 0.3987 & 1.0000 & & & & \\
\hline closestair $\sim \mathrm{m}$ & -0.1332 & -0.1531 & 0.1223 & 1.0000 & & & \\
\hline raiway & 0.3169 & -0.1299 & -0.1682 & 0.0405 & 1.0000 & & \\
\hline totalstora 2 & 0.5472 & -0.0369 & -0.0112 & -0.1638 & 0.4324 & 1.0000 & \\
\hline import & 0.1886 & -0.1582 & -0.3697 & -0.1006 & 0.0451 & -0.0199 & 1.0000 \\
\hline
\end{tabular}

Figure 3 Correlation between variables

\begin{tabular}{|c|c|c|c|c|c|c|c|c|c|c|c|c|c|c|c|c|c|c|c|c|}
\hline port name & y2009 & y 2010 & y2011 & y2012 & y2013 & y2014 & y 2015 & y2016 & y2017 & y2018 & y2009 & y2010 & y2011 & $y 2012$ & y2013 & y2014 & y2015 & y2016 & y2017 & y2018 \\
\hline Omisalj & 0.71 & 0.71 & 0.57 & 0.50 & 0.53 & 0.40 & 0.55 & 0.79 & 0.95 & 0.99 & 0.77 & 0.76 & 0.61 & 0.53 & 0.55 & 0.42 & 0.57 & 0.81 & 0.96 & 0.99 \\
\hline Ploce & 0.61 & 0.99 & 0.97 & 0.55 & 0.56 & 0.57 & 0.59 & 0.59 & 0.70 & 0.73 & 0.61 & 0.99 & 0.96 & 0.54 & 0.55 & 0.55 & 0.57 & 0.56 & 0.66 & 0.68 \\
\hline Rijeka & 0.98 & 0.74 & 0.73 & 0.85 & 0.80 & 0.89 & 0.99 & 0.81 & 0.90 & 0.99 & 0.99 & 0.75 & 0.73 & 0.85 & 0.79 & 0.87 & 0.97 & 0.78 & 0.86 & 0.93 \\
\hline Spit & 0.80 & 0.99 & 0.81 & 0.99 & 0.99 & 0.90 & 0.88 & 0.76 & 0.81 & 0.75 & 0.81 & 1.0 & 0.80 & 0.98 & 0.96 & 0.87 & 0.85 & 0.72 & 0.76 & 0.70 \\
\hline Ancona & 0.86 & 0.86 & 0.71 & 0.77 & 0.67 & 0.73 & 0.78 & 0.76 & 0.84 & 0.99 & 0.93 & 0.91 & 0.74 & 0.81 & 0.76 & 0.76 & 0.80 & 0.78 & 0.85 & 1.0 \\
\hline Augusta & 0.93 & 0.99 & 0.95 & 0.96 & 0.93 & 0.89 & 0.76 & 0.76 & 0.81 & 0.82 & 0.94 & 0.99 & 0.94 & 0.94 & 0.98 & 0.87 & 0.74 & 0.73 & 0.77 & 0.77 \\
\hline Bari & 0.44 & 0.73 & 0.71 & 0.64 & 0.63 & 0.69 & 0.71 & 0.88 & 0.88 & 0.99 & 0.47 & 0.78 & 0.75 & 0.67 & 0.71 & 0.71 & 0.73 & 0.90 & 0.89 & 1.0 \\
\hline Catania & 0.21 & 0.44 & 0.44 & 0.44 & 0.45 & 0.51 & 0.54 & 0.88 & 0.99 & 0.99 & 0.22 & 0.47 & 0.46 & 0.46 & 0.51 & 0.53 & 0.56 & 0.90 & 0.99 & 0.99 \\
\hline Civitavecchia & 0.41 & 0.51 & 0.54 & 0.97 & 0.92 & 0.88 & 0.95 & 0.90 & 0.86 & 0.99 & 0.43 & 0.52 & 0.55 & 0.98 & 0.99 & 0.88 & 0.94 & 0.89 & 0.84 & 0.96 \\
\hline F. Marittima & 0.95 & 0.90 & 0.93 & 0.69 & 0.59 & 0.90 & 0.92 & 0.99 & 0.90 & 0.90 & 1.0 & 0.94 & 0.96 & 0.70 & 0.64 & 0.90 & 0.93 & 0.99 & 0.89 & 0.87 \\
\hline Genova & 0.83 & 0.81 & 0.82 & 0.82 & 0.79 & 0.84 & 0.84 & 0.87 & 0.98 & 0.99 & 0.90 & 0.86 & 0.87 & 0.86 & 0.89 & 0.87 & 0.87 & 0.89 & 0.99 & 0.99 \\
\hline Livorno & 0.73 & 0.75 & 0.70 & 0.67 & 0.79 & 0.80 & 0.96 & 0.89 & 0.92 & 0.99 & 0.79 & 0.80 & 0.74 & 0.71 & 0.88 & 0.83 & 0.99 & 0.91 & 0.94 & 1.0 \\
\hline M. Carrara & 0.71 & 0.88 & 0.99 & 0.96 & 0.56 & 0.47 & 0.42 & 0.42 & 0.50 & 0.68 & 0.73 & 0.89 & 1.0 & 0.95 & 0.59 & 0.47 & 0.41 & 0.40 & 0.48 & 0.64 \\
\hline Monfalcone & 0.99 & 0.62 & 0.70 & 0.75 & 0.79 & 0.85 & 0.87 & 0.93 & 0.97 & 0.95 & 1.0 & 0.61 & 0.68 & 0.73 & 0.82 & 0.82 & 0.83 & 0.88 & 0.91 & 0.88 \\
\hline Napoli & 0.65 & 0.92 & 0.86 & 0.78 & 0.81 & 0.82 & 0.99 & 0.93 & 0.95 & 0.95 & 0.68 & 0.95 & 0.88 & 0.80 & 0.88 & 0.83 & 0.99 & 0.93 & 0.93 & 0.92 \\
\hline Oristano & 0.66 & 0.65 & 0.79 & 0.71 & 0.60 & 0.62 & 0.63 & 0.70 & 0.68 & 0.99 & 0.71 & 0.69 & 0.83 & 0.74 & 0.67 & 0.64 & 0.65 & 0.71 & 0.69 & 0.99 \\
\hline Ortona & 0.72 & 0.80 & 0.99 & 0.98 & 0.95 & 0.80 & 0.83 & 0.80 & 0.69 & 0.85 & 0.72 & 0.80 & 0.98 & 0.96 & 1.0 & 0.77 & 0.80 & 0.76 & 0.66 & 0.80 \\
\hline Palermo & 0.61 & 0.66 & 0.73 & 0.78 & 0.79 & 0.73 & 0.74 & 0.85 & 0.93 & 0.99 & 0.66 & 0.71 & 0.77 & 0.82 & 0.88 & 0.75 & 0.76 & 0.87 & 0.94 & 0.99 \\
\hline Piombino & 0.99 & 0.95 & 0.82 & 0.85 & 0.72 & 0.45 & 0.36 & 0.41 & 0.31 & 0.41 & 1.0 & 0.94 & 0.85 & 0.82 & 0.74 & 0.43 & 0.34 & 0.39 & 0.29 & 0.38 \\
\hline Ravenna & 0.77 & 0.72 & 0.72 & 0.72 & 0.72 & 0.78 & 0.81 & 0.88 & 0.94 & 0.99 & 0.83 & 0.76 & 0.76 & 0.76 & 0.81 & 0.80 & 0.84 & 0.90 & 0.95 & 1.0 \\
\hline Salerno & 0.60 & 0.61 & 0.68 & 0.69 & 0.76 & 0.83 & 0.92 & 0.98 & 0.99 & 0.97 & 0.64 & 0.64 & 0.70 & 0.72 & 0.84 & 0.85 & 0.94 & 0.99 & 1.0 & 0.96 \\
\hline Savona & 0.99 & 0.81 & 0.93 & 0.89 & 0.87 & 0.69 & 0.76 & 0.85 & 0.79 & 0.86 & 0.99 & 0.80 & 0.91 & 0.86 & 0.91 & 0.66 & 0.73 & 0.80 & 0.74 & 0.80 \\
\hline Taranto & 0.92 & 0.83 & 0.99 & 0.85 & 0.59 & 0.56 & 0.44 & 0.50 & 0.48 & 0.48 & 0.94 & 0.84 & 0.99 & 0.85 & 0.63 & 0.55 & 0.43 & 0.49 & 0.46 & 0.46 \\
\hline Trieste & 0.71 & 0.71 & 0.73 & 0.73 & 0.80 & 0.82 & 0.85 & 0.85 & 0.96 & 0.99 & 0.77 & 0.75 & 0.77 & 0.77 & 0.90 & 0.85 & 0.88 & 0.87 & 0.97 & 0.99 \\
\hline Venezia & 0.99 & 0.98 & 0.95 & 0.92 & 0.86 & 0.75 & 0.93 & 0.93 & 0.93 & 0.97 & 0.99 & 0.97 & 0.92 & 0.89 & 0.89 & 0.72 & 0.89 & 0.89 & 0.87 & 0.90 \\
\hline Koper & 0.58 & 0.63 & 0.70 & 0.73 & 0.74 & 0.78 & 0.86 & 0.91 & 0.96 & 0.99 & 0.63 & 0.68 & 0.75 & 0.77 & 0.78 & 0.81 & 0.89 & 0.93 & 0.97 & 0.99 \\
\hline
\end{tabular}

Figure 4 Technical efficiency results ( te2 and te 3), computed by authors

However, it is evident that for the most efficient and largest ports, the net-effect model te 3 outputs the best results.

This suggests that if ports use imports as an input item in their calculations, they can achieve much better technical efficiency results. In that case, imports not only affect the competitiveness of the port but also possibly participate in making decisions on infrastructure changes, which later directly affects the other technical designations of the ports.

Also, there are the ports with decreasing technical efficiency. Port Taranto came from a value of 0.92 in the year 2009 to value of 0.48 in the year 2018. The Croatian ports Ploce and Split have a similar situation. In these cases, irregularities in the steady rise and fall of technical efficiency are repercussions of crisis years, but another theory that can justify the unevenness is port infrastructural investments (Liu, 2010). Namely, if the port recorded a sudden decrease in efficiency and traffic increased that year, it is possible that the port went through an investment cycle. In this case, the capacity of the port is increased, but until the capacity is refilled there will be a decrease in technical 
efficiency. From Figure 3, it can be observed how the variables are correlated to output. We can get most information about output from the total storage variable, while output does not depend on the closest airport variable. Inefficiency elements in the composite error, from the previously mentioned test, give a share of y with the result of 0.99 . A higher proportion is this case means better preforming results.

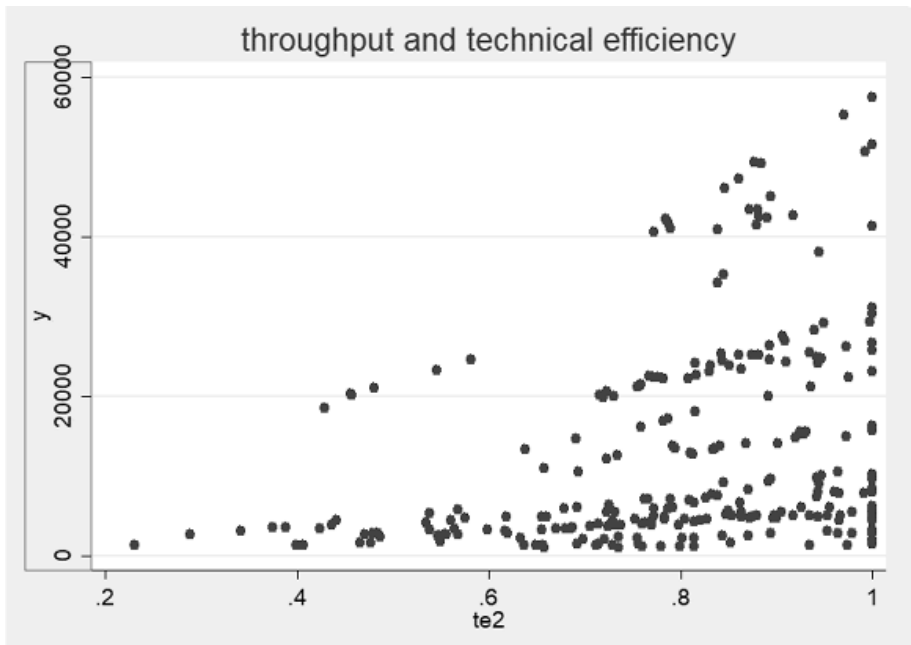

Figure 4 Scatterplot display of technical efficiency (te2)

Figure 5 represents the overall impression of the situation of the ports' technical efficiency. At first glance, it shows that smaller ports are the most efficient, but this is not the case. Namely, the largest number of ports in the survey are smaller ports, which is why the lower right triangle appears to be the most filled. What we can read from this graph is that the larger a port is, the more efficient it is. Smaller ports can be extremely efficient, but due to the even distribution we can see that almost as many are inefficient, and the values are distributed along the line between zero and one.

\section{Conclusion}

Greene's (2005) model application considers the time-varying pattern of efficiency while it also takes into account potential present time invariant firm heterogeneity, which is useful in a panel dataset like ours. We consider that the values given for ports are generally high, but as in results shown by other research, technical efficiency results tend to give higher values in panel data sets over cross-sectional datasets. The positive correlation of the variables with output was demonstrated. It is noticeable that the model in which imports were in the deterministic part gave the best results. Although this might not the case for all ports, we can conclude that the hypothesis was accepted, given that most ports responded positively to this assumption. As provider of service for vessels companies, ports should be able to accept the changes according to the needs of the companies so that port performance can be assessed on the basis of many measures (Lin \& Hualong, 2010). The majority of the examined ports cannot physically accept the largest vessels due to the shallowness of the canals and short docks. As can be concluded from the depth of channel data, it is noticeable that these ports would need serious infrastructure changes that include deepening of the channel to meet market demands. Lately, there are vessels that have a breadth of 58 meters and depths to 32 meters. Our results also indicate that imports and trade, in general, need to be accounted for in order to increase technical efficiency, which affects competitiveness. Simplified, a selective approach to trade data can affect decisions on infrastructure changes that would later affect further improving technical efficiency. There are a number of important limitations that we need to take into consideration. There is no certain agreement among researchers that indicate exactly which variables affect technical efficiency. Also, there is no agreement on the criteria for determining the methodology that is best applied in ports; so, the results can be highly influenced depending on the choice of calculation method.The current study has only examined the largest world ports and the largest European or Mediterranean ports but did not aim at smaller ones. This leads us to an open area for research due to the potential investment in Croatian, Slovenian, and Italian ports. There are several other models of efficiency calculations that should be applied to these ports in order to get a broader picture of the status and prosperity of ports, as well as to perform a study about the growth of ports and changes of the efficiency in the future. 


\section{References}

Aigner, D., Knox, C. A., \& Lovell, P. S. (1977). Formulation and estimation of stochastic frontier production function models. Journal of Econometrics, vol.6, pp. 21-37.

Belotti, F., Daidone, S., Ilardi, G., \& Atella, V. (2013). Stochastic frontier analysis using Stata. The Stata Journal, vol. 4, pp. 719-758.

Coto-Millan, P., Banos-Pino, J., \& Rodriguez-Alvarez, A. (2000). Economic efficiency in Spanish ports: some empirical evidence. The flagship journal of international shipping and port research, vol. 27, pp. 169174.

Cullinane, K., \& Song, D.-W. (2003). A stochastic frontier model of the productive efficiency of Korean container terminals. Applied Economics, vol. 35, pp. 251-267 .

Cummins, J. D., \& Weiss, M. A. (2000). Analyzing Firm Performance in the Insurance Industry Using Frontier Efficiency and Productivity Methods. In D. G., Handbook of Insurance, Huebner International Series on Risk, Insurance, and Economic Security (pp. 767-829). Dordrecht: Springer.

Daraio, C., \& Simar, L. (2007). Advanced Robust and Nonparametric Methods in Efficiency Analysis. Springer US, 13-42.

Greene, W. (2005, January). Fixed and Random Effects in Stochastic Frontier Models. Journal of Productivity Analysis, Vol. 23, No. 1, pp. 7-32.

Kennedy, O. R., Lin, K., Yang, H., \& Ruth, B. (2011.). Sea-Port Operational Efficiency: An Evaluation of Five Asian Ports Using Stochastic Frontier Production Function Model. Journal of Service Science and Management, pp. 391-399.

Koopmans, T. (1951). An analysis of production as an efficient combination of activities. In T. Koopmans, Activity Analysis of Production and Allocation. New York: Monograph No. 13, Wiley.

Krugman, P. (1980). Scale Economies, Product Differentiation, and the Pattern of Trade. The American Economic Review, vol.5, pp. 950-959.

Kumbhakar, S. C., \& Lovell, C. A. (2000). Stochastic Frontier Analysis. Cambridge: Cambridge University Press.

Lin, K., \& Hualong, Y. (2010). Port Throughput Analysis of China and Five member Countries of ASEAN. International Conference on Intelligent Computation Technology and Automation (pp. 914-917). IEEE, Computer Society.

Lin, L.-C., \& Tseng, L.-A. (2005). Application of DEA and SFA on the Measurement of Operating Efficiencies for 27 International Container Ports. Proceedings of the Eastern Asia Society for Transportation Studies, Vol. 5, pp. 592 - 607.

Liu, Q. (2010). Efficiency Analysis of Container Ports and Terminals. London: A thesis submitted for the degree of Doctor of Philosophy of University College London.

Mazorodze, B. (2019.). Trade and efficiency of manufacturing industries in South Africa. The Journal of International Trade \& Economic Development, pp. 2-30.

Meeusen, W., \& Broeck, J. v. (1977). Efficiency Estimation from Cobb-Douglas Production Functions with Composed Error. International Economic Review, vol.18, pp. 435-444.

Notteboom, T., Cook, C., \& Broeck, J. v. (2000). Measuring and Explaining the Relative Efficiency of Container Terminals by means of Bayesian Stochastic Frontier Models. International Journal of Maritime Economics, vol.2, pp. 83-106.

Odeck, J., \& Bråthen, S. (2012). A meta-analysis of DEA and SFA studies of the technical efficiency of seaports: A comparison of fixed and random-effects regression models. Transportation Research Part A: Policy and Practice, vol. 46, pp. 1574-1585.

Pitt, M. M., \& Lee, L. F. (1981.). The measurement and sources of technical inefficiency in the Indonesian weaving industry. Journal of Development Economics, vol. 9, pp. 43-64.

Schøyen, H., \& Odeck, J. (2013). The technical efficiency of Norwegian container ports: A comparison to some Nordic and UK container ports using Data Envelopment Analysis (DEA). Maritime Economics \& Logistics Vol. 15, pp. 197-221. 